\title{
Penetration of Substances into Cold-Shocked Bacteria
}

\author{
By R. E. STRANGE and J. R. POSTGATE \\ Microbiological Research Establishment, Porton, Wiltshire
}

(Received 31 March 1964)

\begin{abstract}
SUMMARY
The death-rate of washed exponential phase Aerobacter aerogenes chilled in saline phosphate buffer $(\mathrm{pH} 6 \cdot 5)$ at $0^{\circ}$ was increased by ribonuclease (RNase) but not by deoxyribonuclease, trypsin, pepsin or lysozyme; none of these enzymes had any immediate effect on the viability of similar bacterial suspensions at $20^{\circ}$. Leakage products from chilled $A$. aerogenes, $\mathrm{Mg}^{2+}$ and, to a smaller extent, $0.3 \mathrm{M}$-sucrose, antagonized the lethal effect of RNase on chilled organisms. RNA degradation occurred when bacteria were chilled and then incubated in fresh diluent at $37^{\circ}$; organisms exposed to RNase during chilling degraded RNA at $20-25^{\circ}$ when the rate of autodegradation of RNA was low. As the salt content of the environment was decreased, the amount of RNase adsorbed by the bacteria and its lethal effect increased at both $0^{\circ}$ and $20^{\circ}$; in distilled water RNase was more lethal at $20^{\circ}$ than at $0^{\circ}$. Anilino-naphthalene-8-sulphonate penetrated into bacteria chilled in buffer containing this dye. Acid or alkali accelerated the death rate of bacteria to greater extents at $0^{\circ}$ than at $20^{\circ}$. RNase increased the lethal effect of freezing and thawing on a population from a continuous culture and augmented subsequent degradation of RNA.
\end{abstract}

\section{INTRODUCTION}

The lethal effect of chilling on certain bacteria, which is called 'cold shock' (Sherman \& Albus, 1923; Hegarty \& Weeks, 1940; Gorrill \& McNeil, 1960), may be due to interference with bacterial permeability control mechanisms (Meynell, 1958). Evidence for this view is that leakage of normal endocellular constituents occurs when susceptible bacteria are chilled (Strange \& Dark, 1962; Strange \& Ness, 1963). Evidence that substances penetrate from the environment into chilled bacteria to a greater extent than into unchilled bacteria would provide further support for this hypothesis. The present paper presents evidence that RNase, anilino-napthalene-8-sulphonate, hydrogen ions and hydroxyl ions more readily enter bacteria subjected to cold shock or freezing and indicates that the permeability damage is, in the absence of RNase, sometimes reversible.

\section{METHODS}

Organism and cultural conditions. Strain NCTC418 of Aerobacter aerogenes was grown at $37^{\circ}$ in shaken flasks (2 1.) containing the mannitol-limiting defined medium (100 ml.) previously described (Strange, Dark \& Ness, 1961) seeded with 1-4 ml. of a fully grown (18-20 hr) culture (about $10^{10}$ viable bacteria/ml.) in the same medium. Bacteria growing exponentially were harvested after growth for 2-4 hr.

Viability determinations. The \% viable bacteria in a suspension was determined 
microscopically with dark-ground illumination after slide culture on the rich medium described by Postgate, Crumpton \& Hunter (1961) except that glucose $(0.5 \%, \mathrm{w} / \mathrm{v})$ replaced glycerol $(0.2 \%, \mathrm{w} / \mathrm{v})$. In a few experiments the results were checked by plate counts; samples $(\mathbf{0} \cdot \mathbf{2} \mathbf{~ m l}$.) of a suspension suitably diluted in saline phosphate buffer ( $\mathrm{pH} \mathrm{6.5)}$ were spread on each of 3 or 5 plates of Oxoid Plate Count Agar (from Oxo Ltd.) and the colonies counted after incubation for $24 \mathrm{hr}$ at $37^{\circ}$.

Chilling. Bacteria separated from a culture by centrifugation were washed once or twice with diluent and resuspended at a suitable concentration in the same diluent. Washed suspensions were chilled by dilution (1/10-1/50) into diluent held in a temperature controlled bath at $0^{\circ}$. Saline phosphate buffer diluent was prepared from a stock solution containing $2 \cdot 2 \mathrm{M}-\mathrm{NaCl}$ and appropriate concentrations of $\mathrm{K}_{2} \mathrm{HPO}_{4}+\mathrm{KH}_{2} \mathrm{PO}_{4}\left(0 \cdot 4 \mathrm{M}-\mathrm{PO}_{4} ; \mathrm{pH} 6 \cdot 5\right)$; just before use the stock solution was diluted with fresh glass-distilled water either $1 / 20$ or more usually $1 / 40$ ('dilute saline phosphate buffer' contained $0.055 \mathrm{M}-\mathrm{NaCl}$ and $0.01 \mathrm{M}-\mathrm{PO}_{4}$ ) and filtered through well-washed Oxoid membrane filters (grade A.P.; Oxo Ltd.).

Incubation of chilled bacteria. Usually bacteria in a sample of chilled suspension (10-20 ml.; equiv. 0.4-0.5 mg. bacterial dry wt./ml.) were quickly sedimented in the chilled head of an M.S.E. Angle-13 high-speed centrifuge, rinsed twice with cold diluent (gently poured on and off the pellet) and resuspended in aerated diluent at $25^{\circ}$ or $37^{\circ}$.

Freezing. Bacteria were frozen in liquid nitrogen and thawed, with the techniques and populations described by Postgate \& Hunter (1961).

Enzymes. Samples of crystalline pancreatic ribonuclease (RNase) 'free from salt and protease' were obtained from the Worthington Biochemical Corp. (Freehold, New Jersey, U.S.A.) and L. Light and Co. Ltd.; a third sample of crystalline RNase was obtained from British Drug Houses, Ltd. Crystalline 'Tryptar' trypsin was obtained from The Armour Laboratories (Hampden Park, Eastbourne), crystalline muramidase and pepsin from L. Light and Co. Ltd. and non-crystalline deoxyribonuclease (DNase; activity equiv. crystalline enzyme) from the Sigma Chemical Co. Ltd. (St Louis, Missouri, U.S.A.).

Analytical methods. Cold acid-extracts of bacterial suspensions were prepared by adding the suspension $\left(2.5 \mathrm{ml}\right.$.) to $2 \mathrm{~N}-\mathrm{HClO}_{4}\left(0.5 \mathrm{ml}\right.$.) at $0^{\circ}$. After $30 \mathrm{~min}$. the acid suspensions were centrifuged and the supernatant fluids separated. Hot acidextracts of the bacteria were prepared by resuspending the cold acid-extracted pellets in $0.5 \mathrm{~N}-\mathrm{HClO}_{4}\left(5 \mathrm{ml}\right.$.) for $30 \mathrm{~min}$. at $70^{\circ}$. RNA in hot acid-extracts was determined by the Bial reaction (Morse \& Carter, 1949) with yeast RNA as the standard. RNase activity was determined by measurements at $260 \mathrm{~m} \mu$ of the acid-soluble ultraviolet (u.v.) absorbing substances released from yeast RNA after exposure to the test enzyme solution for $25 \mathrm{~min}$. at $25^{\circ}$ (Joseffson \& Lagerstedt, 1962). U.v.-absorption was measured in a Unicam quartz spectrophotometer, model SP. 500, with a $1 \mathrm{~cm}$. light path. The fluorescence of bacterial suspensions treated with anilino-naphthalene-8-sulphonic acid (ANS) was measured in a fluorometer supplied by The Locarte Company, 24 Emperor's Gate, S.W. 7. Bacterial dry weights were determined as previously described (Strange et al. 1961). 


\section{RESULTS}

\section{Enhancement of cold shock by RNase}

According to viability determinations by slide culture (Fig. 1) or plate counts, RNase (10-100 $\mu \mathrm{g} . / \mathrm{ml}$.) increased the death-rate of exponential phase Aerobacter aerogenes washed and resuspended in dilute saline phosphate buffer at $0^{\circ}$, but had no immediate effect on similar unchilled suspensions at $20^{\circ}$. In this diluent at $0^{\circ}$, RNase only affected bacterial populations susceptible to the lethal effect of cold shock; stationary-phase bacteria from batch culture or steadily growing bacteria from a continuous culture (Postgate \& Hunter, 1962) were not significantly affected by chilling either with or without RNase. On a given batch of organisms, the lethal effect differed according to the sample of $\mathrm{RNase}$ used. $\mathrm{Mg}^{2+}$ or filtrate from a chilled dense bacterial suspension, which protect bacteria from the lethal effect of cold shock (Strange \& Dark, 1962), also protected bacteria chilled in the presence of RNase (Table 1). Sucrose $(0 \cdot 3 \mathrm{M})$, which also protects bacteria during chilling (Meynell, 1958; Strange \& Dark, 1962), afforded slight protection in the presence of

\section{Table 1. Inhibition of the lethal effect of RNase on Aerobacter aerogenes in dilute saline phosphate buffer at $0^{\circ}$}

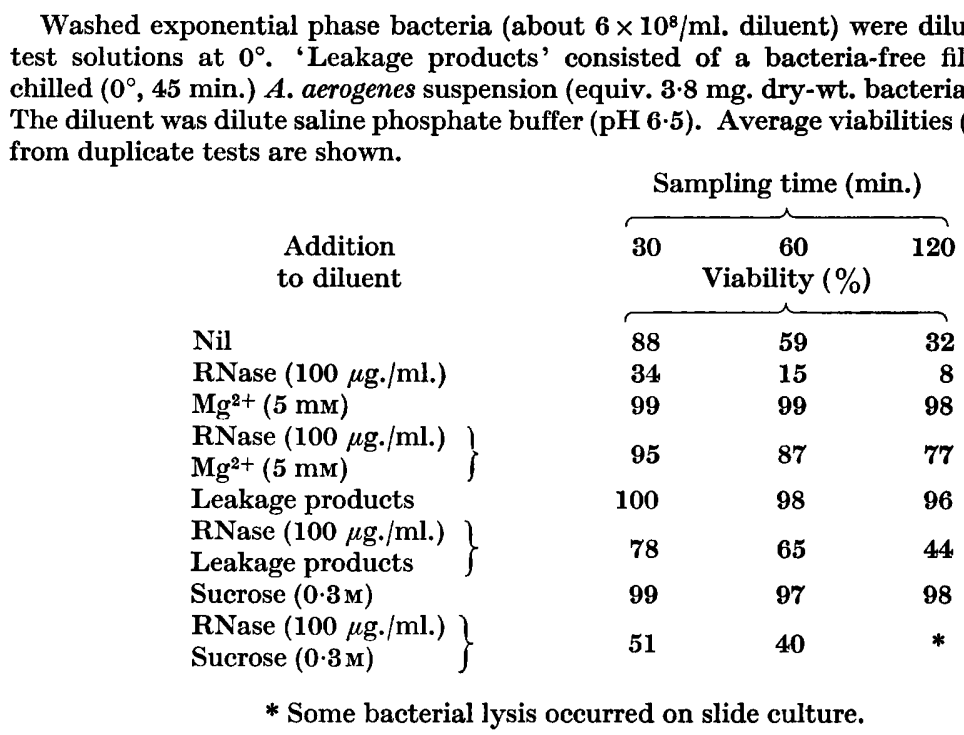

RNase (Table 1). In stronger saline phosphate buffer $\left(0 \cdot 11 \mathrm{M}-\mathrm{NaCl}+\mathbf{0} \cdot 02 \mathrm{M}-\mathrm{PO}_{4}\right.$; $\mathrm{pH} 6 \cdot 5$ ), similar results were usually obtained, but in a few experiments (four out of nineteen) with bacteria that were less than normally susceptible to cold shock, RNase did not increase the death-rate.

Tests with other enzymes. Pepsin or DNase $(100 \mu \mathrm{g} . / \mathrm{ml}$.) had no significant effect on the death-rate of bacteria in saline phosphate buffer at $0^{\circ}$, whereas trypsin or muramidase (100 $\mu \mathrm{g} . / \mathrm{ml}$.) were protective (Fig. 2). These enzymes had no immediate effect on the viability of similar bacterial suspensions at $20^{\circ}$. 


\section{RNA metabolism on incubation of cold shocked bacteria}

Enhancement of cold shock by RNase would result from penetration of the enzyme into the bacteria followed by degradation of cellular RNA when the organisms were warmed on the recovery medium. Attempts were therefore made to confirm the entry of RNase into chilled bacteria by demonstrating an increased rate

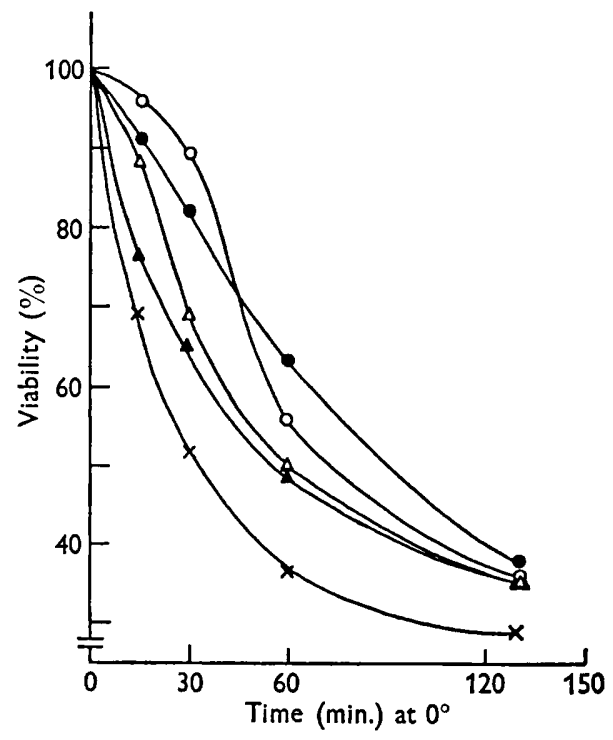

Fig. 1

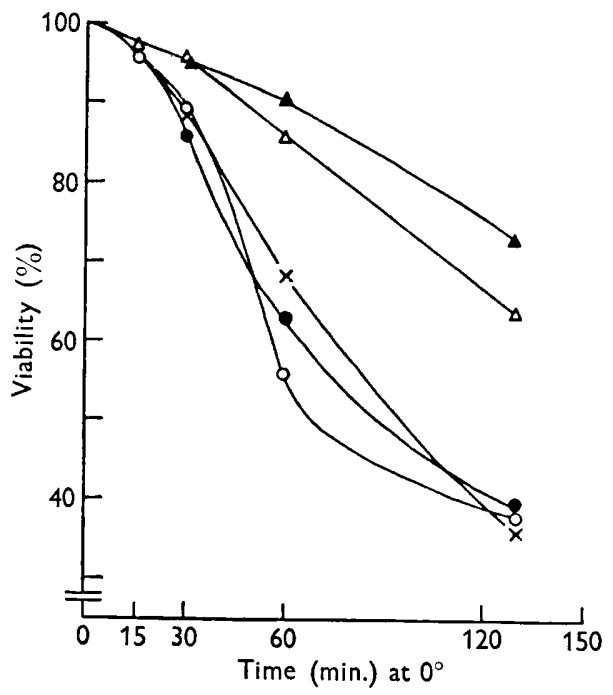

Fig. 2

Fig. 1. Survival of Aerobacter aerogenes at $0^{\circ}$ in the presence of RNase. Washed exponential phase bacteria (about $4 \times 10^{8} / \mathrm{ml}$. dilute saline phosphate buffer) were diluted $1 / 20$ in diluents with and without $R$ Nase at $0^{\circ}$ and $20^{\circ}$. Viabilities (slideculture) of bacteria at $0^{\circ}$ in dilute saline phosphate buffer alone $(O)$ and with $10,25,50$ and $100 \mu \mathrm{g} . / \mathrm{ml}$. RNase $\left(\odot, \Delta, \Delta, \times\right.$, respectively). Viabilities of suspensions at $20^{\circ}$ were $98-100 \%$ for $130 \mathrm{~min}$.

Fig. 2. Survival of Aerobacter aerogenes at $0^{\circ}$ in the presence of various enzymes. Viabilities of bacterial suspensions (prepared as in Fig. 1) at $0^{\circ}$ in dilute saline phosphate buffer alone $(O)$ and with $(100 \mu \mathrm{g} . / \mathrm{ml}$.) DNase $(\odot)$, trypsin $(\triangle)$, pepsin $(x)$ and lysozyme $(\Delta)$. Viabilities of similar suspensions at $20^{\circ}$ were $98-100 \%$ for $130 \mathrm{~min}$.

of RNA degradation during subsequent incubation of the organisms. At $37^{\circ}$, these attempts failed because cold shock itself stimulated autodegradation of RNA: when bacteria were chilled for various times, separated from the suspensions, resuspended in fresh diluent and incubated at $37^{\circ}$, RNA degradation increased with the duration of chilling (Table 2). RNA degradation in a bacterial population previously chilled in the presence of RNase did not differ significantly from that in a comparable population decreased to about the same degree of viability by chilling for a longer period in buffer alone when tested at $37^{\circ}$. However, when cold-shocked bacterial populations of similar viabilities were subsequently incubated at $20^{\circ}$ or $25^{\circ}$, RNA degradation was consistently greater when RNase had been present during chilling (Fig. 3). Little RNA degradation occurred in bacteria exposed to RNase at $20^{\circ}$ and then subsequently incubated at $37^{\circ}$.

Effect of late addition of RNase. The foregoing experiments showed that cold shock rendered a proportion of a chilled bacterial population sufficiently permeable 
to admit RNase. Those organisms that would not otherwise have recovered from cold shock should be sufficiently permeable to admit RNase added after chilling, though in such conditions the added RNase would only increase the rate of degradation of RNA by the population and not its death-rate. The experiments in Fig. 4 illustrate this effect: RNase added after chilling accelerated RNA degradation but not death. RNase tested at one-tenth the concentration quoted in Fig. 4 had no detectable effect.

\section{Table 2. $R N A$ degradation at $37^{\circ}$ in Aerobacter aerogenes chilled for various times at $0^{\circ}$}

\begin{tabular}{|c|c|c|c|c|c|c|}
\hline \multicolumn{7}{|c|}{$\begin{array}{l}\text { Washed exponential-phase bacteria (equiv. } 4 \mathrm{~m} \\
\text { diluent at } 0^{\circ} \text {. Bacteria centrifuged from chilled } \\
\text { resuspended in aerated diluent ( } 10 \mathrm{ml} \text {.) at } 37^{\circ} \text {. Viab } \\
\text { were determined at intervals. The diluent was dilu } \\
\text { Time of incubation at } 37^{\circ} \\
\text { (min.) }\end{array}$} \\
\hline $\begin{array}{c}\text { Time at } 0^{\circ} \\
\text { (min.) }\end{array}$ & \multicolumn{3}{|c|}{$\%$ initial RNA left } & \multicolumn{3}{|c|}{ Viability (\%) } \\
\hline $\mathbf{0}$ & 100 & - & 98 & 99 & 99 & 99 \\
\hline 30 & 99 & 78 & 64 & 75 & 32 & - \\
\hline 60 & 86 & 64 & 43 & 33 & 28 & 25 \\
\hline 120 & 87 & 54 & 28 & $7 \cdot 7$ & $7 \cdot 4$ & $6 \cdot 9$ \\
\hline
\end{tabular}

Adsorption of RNase onto bacteria. In contrast to its behaviour in saline phosphate buffer, RNase in distilled water was more lethal to bacteria at $20^{\circ}$ than at $0^{\circ}$. In a typical experiment exponential-phase Aerobacter aerogenes washed in distilled water were resuspended at about $4 \times 10^{7} \mathrm{bacteria} / \mathrm{ml}$. in distilled water and in distilled water + RNase $\left(100 \mu \mathrm{g} . / \mathrm{ml}\right.$.) at $20^{\circ}$ and $0^{\circ}$. Viabilities of the suspensions after $10 \mathrm{~min}$. were 100 and $1.6 \%$, respectively, at $20^{\circ} ; 99.5$ and $56 \%$, respectively, at $0^{\circ}$. In parallel with the lethal effect, there was considerable bacterial adsorption of enzyme (Table 3). It appeared that the uptake of enzyme was due to adsorption, not absorption, because after separating the bacteria by centrifugation and resuspending them in $0.16 \mathrm{M}-\mathrm{NaCl}, \mathrm{RNase}$ roughly equivalent to that taken up from distilled water was released into the salt solution. Adsorption of RNase to bacteria was progressively inhibited by increasing concentrations of $\mathrm{NaCl}$ or $\mathrm{KCl}$. The lethal effect of RNase at $20^{\circ}$ also decreased with increasing salt concentration (Fig. 5).

\section{Penetration of anilino-naphthalene-sulphonate (ANS) into chilled bacteria}

ANS like the toluidine homologue used by Newton (1954), forms a fluorescent complex with Aerobacter aerogenes when the osmotic barrier is destroyed, and it has been used to test for damage to that barrier (Mathews \& Sistrom, 1960; Postgate $\&$ Hunter, 1962). If bacterial permeability is affected by cold shock, the dye might penetrate chilled bacteria, causing an increase in the fluorescence of the suspension. A small but significant increase in the fluorescence of a suspension of exponential phase $A$. aerogenes containing ANS was observed on chilling (Table 4). The viability of the chilled suspension decreased more rapidly after exposure to ANS for $30 \mathrm{~min}$. than that of a similar population of bacteria chilled in the absence of dye. 


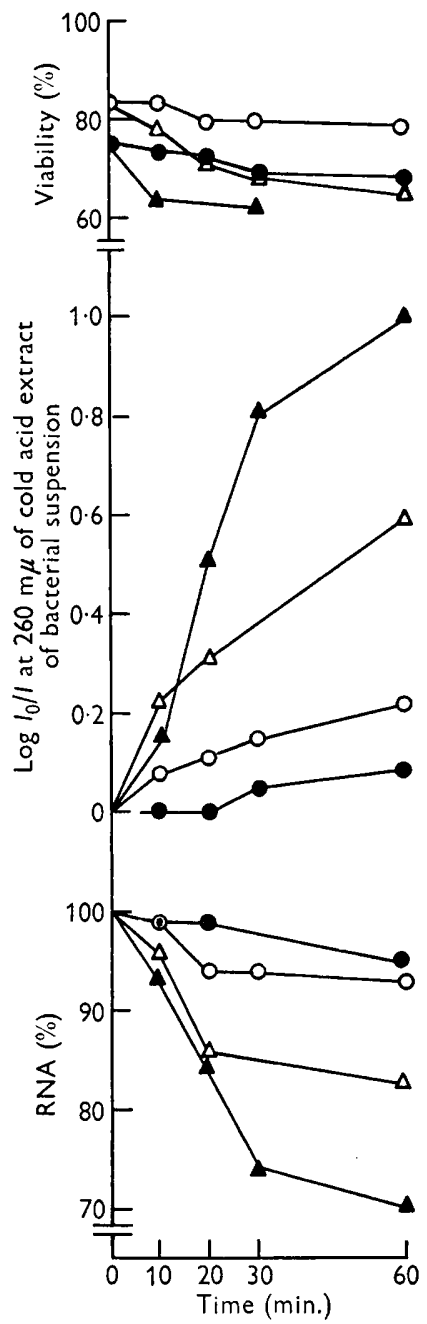

Fig. 3

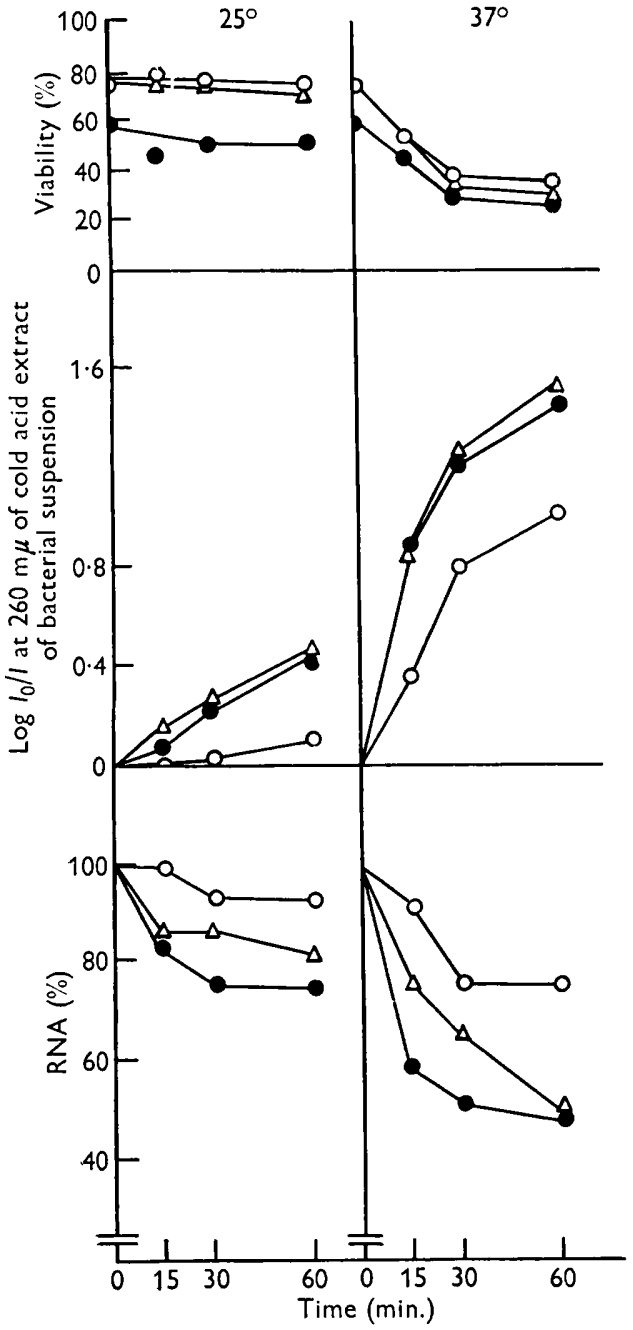

Fig. 4

Fig. 3. RNA metabolism in Aerobacter aerogenes after chilling in the presence and absence of RNase. Washed exponential phase bacteria (equiv. 6.6 mg. dry wt./ml. diluent) were diluted $1 / 15$ in duplicate in cold $(a)$ diluent + RNase $(100 \mu \mathrm{g} . / \mathrm{ml}$.$) , (b)$ diluent. After chilling (a) $30 \mathrm{~min}$. and (b) $60 \mathrm{~min}$. the suspensions were centrifuged at $0^{\circ}$. After rinsing with cold diluent, one of each pair of bacterial pellets was resuspended in diluent (12 ml.) at $25^{\circ}$, the other at $37^{\circ}$. At intervals samples were taken for viability (slide culture) and analyses. Bacteria chilled in presence of RNase, open symbols; in diluent alone, closed symbols. Suspensions at $25^{\circ} \mathrm{O}, \mathrm{O} ; 37^{\circ} \triangle, \Delta$. Top, viabilities. Middle, $E_{260 \mathrm{~m} \mu}^{1 \mathrm{~cm}}$ of cold acidextracts. Bottom, bacterial RNA (\% initial concentration). The diluent was dilute saline phosphate buffer.

Fig. 4. Bacterial RNA degradation after chilling in the presence of RNase and after chilling in the absence but incubating in the presence of RNase. Washed exponential phase bacteria (equiv. 6.09 mg. dry wt. $/ \mathrm{ml}$. diluent) were diluted $1 / 10$ in cold $(a)$ diluent $+\mathrm{RNase}$ $(100 \mu \mathrm{g} . / \mathrm{ml}),.(b)$ diluent. After $15 \mathrm{~min}$. at $0^{\circ}$, two samples $(10 \mathrm{ml}$.) of $(a)$ were centrifuged and the pellets resuspended in diluent $\left(10 \mathrm{ml}\right.$.) at $25^{\circ}$ and $37^{\circ}$. After $45 \mathrm{~min}$. at $0^{\circ}$, four samples $(10 \mathrm{ml}$.) of $(b)$ were centrifuged and the pellets resuspended in $10 \mathrm{ml}$. of $(1)$ diluent, and (2) diluent + RNase $\left(100 \mu \mathrm{g} . / \mathrm{ml}\right.$.) at $20^{\circ}$ and $37^{\circ}$. Bacteria $(a)$ chilled in presence of RNase (O), (b) chilled without RNase and incubated (1) without RNase (O), and (2) with $100 \mu \mathrm{g} . / \mathrm{ml}$. RNase $(\triangle)$. Top, viability (slide culture); middle, $E_{260 \mathrm{~m} \mu}^{1 \mathrm{~cm}}$ of cold acid extracts; bottom, bacteria RNA (\% initial concentration). Incubation at $25^{\circ}$, left, at $37^{\circ}$, right. The diluent was dilute saline phosphate buffer. 


\section{Effect of hydrogen and hydroxyl ions on the viability of chilled bacteria}

Exponential phase Aerobacter aerogenes, washed and resuspended in glass-distilled water, were tested at a concentration of about $4.5 \times 10^{7}$ bacteria $/ \mathrm{ml}$. As found previously (Strange \& Dark, 1962), populations of these bacteria in distilled water were much less susceptible to cold shock than similar populations in saline phosphate buffer. Low concentrations of acid added to distilled water were much more lethal

\section{Table 3. Adsorption of RNase by Aerobacter aerogenes}

Water-washed exponential phase bacteria (equiv. $49 \mathrm{mg}$. dry wt./ml. distilled water) were diluted $1 / 11$ in $0-0.16 \mathrm{M}-\mathrm{NaCl}\left(1 \mathrm{ml}\right.$.) containing RNase $\left(100 \mu \mathrm{g}\right.$.). After $10 \mathrm{~min}$. at 20 ${ }^{\circ}$, supernatant fluids from the centrifuged suspensions were separated and assayed for $R$ Nase. Bacterial pellets were resuspended in $0.16 \mathrm{M}-\mathrm{NaCl}\left(1 \mathrm{ml}\right.$.). After $15 \mathrm{~min}$. at $0^{\circ}$, supernatant fluids were separated and assayed for RNase released from the bacteria.

\begin{tabular}{|c|c|c|}
\hline $\begin{array}{c}\mathrm{NaCl} \\
(\mathrm{M})\end{array}$ & $\begin{array}{c}\text { Adsorption of RNase } \\
\text { by bacteria } \\
\%\end{array}$ & $\begin{array}{c}\text { Release of RNase } \\
\text { from bacteria in } \\
0 \cdot 16 \mathrm{M}-\mathrm{NaCl} \\
\%\end{array}$ \\
\hline 0 & 95 & 96 \\
\hline 0.01 & 51 & 67 \\
\hline 0.02 & 32 & 34 \\
\hline 0.04 & 14 & 18 \\
\hline 0.08 & 10 & 11 \\
\hline $0 \cdot 16$ & 10 & 5 \\
\hline
\end{tabular}

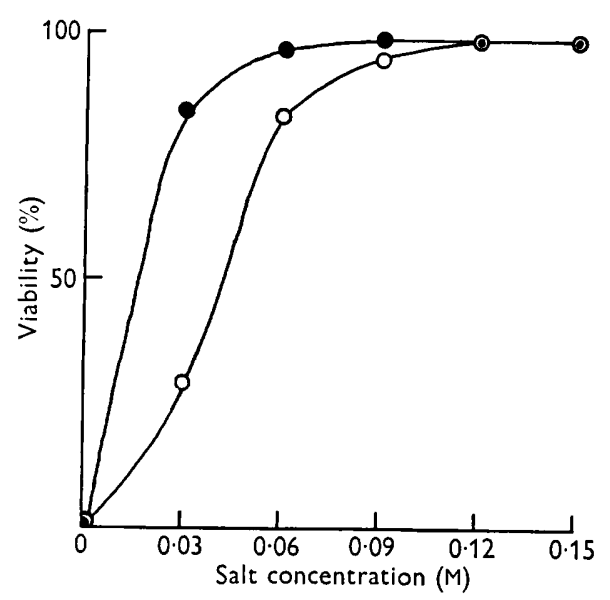

Fig. 5. Salt inhibition of the lethal effect of RNase on bacteria. Water-washed exponential phase bacteria (about $8 \times 10^{8} / \mathrm{ml} . \mathrm{H}_{2} \mathrm{O}$ ) were diluted $1 / 20$ in $0-0 \cdot 15 \mathrm{M}-\mathrm{NaCl}(\mathrm{O})$ and $\mathrm{KCl}$ (O) containing RNase (100 $\mu \mathrm{g} . / \mathrm{ml}$.) at $20^{\circ}$. Viabilities determined by slide culture after 30 min.

to bacteria at $0^{\circ}$ than at $20^{\circ}$ : viabilities of suspensions after 5,10 and $20 \mathrm{~min}$. in $2 \mathrm{~mm}-\mathrm{HCl}(\mathrm{pH} 2 \cdot 7)$ were 78,61 and $35 \%$, respectively, at $0^{\circ} ; 93.5,88$ and $80 \%$, respectively, at $20^{\circ}$. When $50 \mathrm{~mm}-\mathrm{NaCl}$ was added to $2 \mathrm{~mm}-\mathrm{HCl}$, the lethal effect increased: viabilities of similar suspensions after times as above were 16, 4 and $<1 \%$, respectively, at $0^{\circ} ; 67,18$ and $2 \%$, respectively, at $20^{\circ}$. Similarly, low 
concentrations of alkali were more lethal at $0^{\circ}$ than at $20^{\circ}$ : viabilities of suspensions after 5, 10 and $20 \mathrm{~min}$. in $2 \mathrm{~mm}-\mathrm{NaOH}\left(\mathrm{pH} \mathrm{10.9)}\right.$ were $<1 \%$ at $0^{\circ} ; 99.5,99.5$ and $98.5 \%$, respectively, at $20^{\circ}$. Even $0.5 \mathrm{~mm}-\mathrm{NaOH}(\mathrm{pH} \mathrm{10} 1)$ was lethal to bacteria at $0^{\circ}$ : viabilities of suspensions in this diluent after 15 and $30 \mathrm{~min}$. were 7 and $2 \%$, respectively, at $0^{\circ} ; 100$ and $99 \%$, respectively, at $20^{\circ}$. Addition of $50 \mathrm{~mm}-\mathrm{NaCl}$ to $2 \mathrm{~mm}-\mathrm{NaOH}$ increased the lethal effect at $20^{\circ}$ but decreased it at $0^{\circ}$. The effect of small concentrations of $\mathrm{NH}_{4} \mathrm{OH}$ was similar to that of $\mathrm{NaOH}$ but ammonium ions ( 1 to $100 \mathrm{~mm}-\mathrm{NH}_{4} \mathrm{Cl} ; \mathrm{pH} 6 \cdot 3-5 \cdot 3$ ) had no significant effect on the viability of chilled bacteria.

Table 4. Penetration of anilino-naphthalene-8-sulphonate (ANS) into chilled Aerobacter aerogenes

Washed exponential phase bacteria (about $6 \times 10^{8} / \mathrm{ml}$. diluent) were diluted $1 / 20$ at $0^{\circ}$ and $20^{\circ}$ in diluent and diluent + ANS $(50 \mu \mathrm{M})$. At intervals fluorescence and viability (slide culture) of appropriate suspensions were measured. The fluorometric 'blank' was a bacterial suspension without dye at $20^{\circ}$; the 'standard', a similar suspension heated at $70^{\circ}$ for 5 min., cooled and treated with ANS. The diluent was saline phosphate buffer $(\mathrm{pH} 6 \cdot 5)$

\begin{tabular}{|c|c|c|c|}
\hline Sample & $\begin{array}{l}\text { Time } \\
\text { (min.) }\end{array}$ & $\begin{array}{l}\text { Fluorometer } \\
\text { reading } \\
\text { (scale div.) }\end{array}$ & $\begin{array}{c}\text { Viability } \\
\%\end{array}$ \\
\hline Standard & $\overline{c o}$ & 14 & - \\
\hline Bacterial suspension + ANS at $20^{\circ}$ & 60 & $8 \cdot 2$ & 98 \\
\hline Bacterial suspension + ANS at $0^{\circ}$ & $\begin{array}{r}5 \\
10 \\
15 \\
20 \\
30 \\
60\end{array}$ & $\begin{array}{l}8 \cdot 75 \\
9 \cdot 25 \\
9 \cdot 30 \\
9 \cdot 40 \\
9 \cdot 25 \\
9 \cdot 65\end{array}$ & $\begin{array}{l}86 \cdot 5 \\
80 \cdot 5 \\
77 \cdot 5 \\
69 \cdot 0 \\
63 \cdot 0 \\
16 \cdot 0\end{array}$ \\
\hline Bacterial suspension at $0^{\circ}$ & $\begin{array}{l}15 \\
30 \\
60\end{array}$ & - & $\begin{array}{l}63 \cdot 5 \\
62 \cdot 0 \\
49 \cdot 0\end{array}$ \\
\hline
\end{tabular}

Table 5. Augmentation of freezing damage to Aerobacter aerogenes by RNase

Bacteria harvested from a continuous culture (Postgate \& Hunter, 1962) were washed in distilled water and resuspended (equiv. $1 \mathrm{mg}$. dry wt. $/ \mathrm{ml}$.) in distilled water, with or without RNase (100 $\mu \mathrm{g} . / \mathrm{ml}$.). After freezing the suspensions as drops in liquid $\mathrm{N}_{2}$ and thawing them by dilution in saline phosphate buffer $(\mathrm{pH} 7 \cdot 3)$ at $20^{\circ}$, viabilities were determined by slide culture. After $30 \mathrm{~min}$. at $20^{\circ}$, the populations were again frozen and thawed. The viabilities of control populations with and without $R$ Nase at $20^{\circ}$ remained unchanged $(97 \%)$ for the duration of the experiment.

\begin{tabular}{ccc} 
Treatment of bacterial & \multicolumn{2}{c}{ Viability (\%) } \\
\cline { 2 - 3 } $\begin{array}{c}\text { Distilled } \\
\text { water }\end{array}$ & $\begin{array}{c}\text { Distilled water } \\
+ \text { RNase }(100 \mu \mathrm{g} . / \mathrm{ml} .)\end{array}$ \\
Unfrozen & 97 & $\mathbf{9 7}$ \\
Frozen once & $\mathbf{3 7}$ & 5 \\
Frozen twice & 19 & $<1$
\end{tabular}

\section{Effect of $R$ Nase on frozen and thawed bacteria}

The experiments on cold shock imply that some damage occurs to chilled bacteria which may not be lethal unless RNase is present. Postgate \& Hunter (1963) examined metabolic injury resulting from freezing and thawing a bacterial population obtained 
from a chemostat, and further experiments with this population showed that RNase augmented freezing damage, though the populations were insusceptible to cold shock; Table 5 illustrates these experiments. A comparable augmentation of killing on freezing and thawing in RNase solutions was observed with denser (equiv. $10 \mathrm{mg}$. dry-wt. bacteria/ml.) and sparser (equiv. $0 \cdot 1 \mathrm{mg}$. dry-wt. bacteria/ml.) populations. Experiments analogous to those already described for cold-shocked populations showed that exogenous RNase augmented RNA degradation by the frozen and thawed populations.

\section{DISCUSSION}

Though Groth (1956) found that RNase inhibited growth of a special strain of Bacillus megaterium, and lowered the RNA content of its cultures, RNase is usually inactive towards live bacteria (Brachet, 1955). Our experiments show that cold shock makes cellular RNA accessible to extracellular RNase, and endocellular protein accessible to the dyestuff anilino-naphthalene-sulphonate and thus further support the view mentioned in the Introduction that cold shock entails damage to a permeability regulating system. The increased lethal effects of hydrogen and hydroxyl ions at low temperature are also consistent with this view. The permeability damage is not necessarily lethal, because: (i) cold shock is a progressive process (Strange \& Dark, 1962), and (ii) when RNase is admitted while bacteria are 'open' it accelerates death of organisms which would otherwise have been viable, by augmenting autodegradation of RNA. The partial reversibility of this permeability damage recalls the reversible type of freezing damage described as 'metabolic injury' (see Postgate \& Hunter, 1963), which, unlike cold shock, is not restricted to exponentially growing organisms. Since exogenous RNase enhanced death and RNA degradation in frozen and thawed populations it seems likely that reversible damage to the permeability control mechanism is common to both types of stress and suggests that exponentialphase organisms differ from those growing in a chemostat only in that the latter can reverse the damage more readily.

When a bacterial population is chilled, some individuals are apparently immune and others show various degrees of susceptibility, ranging from immediate death to reversible, time-dependent damage. If susceptibility depends on the permeability status of the organisms this range of responses suggests that an exponentially growing population contains individuals of diverse permeabilities and the differences might be due to variations in permeability during a division cycle. Mitchison (1963) suggested that the permeability of a fission yeast to adenine fluctuates during the individual growth cycle. In an 'open' phase, the bacteria can admit a molecule as large as RNase (mol.wt. of monomer, 14,000; Crestfield, Stein \& Moore, 1962) when chilled, yet they would have been viable were it not for the enzymic activity of this molecule. That bacteria can become permeable to large molecules and remain viable has been known since the discovery of transformation, and the rule-of-thumb procedures sometimes used to induce competence in acceptor strains (see, for example, Young \& Spizizen, 1961) resemble those that might induce susceptibility to cold shock in coliform organisms. A mechanistic relationship between cold shock and transformation is possible and we attempted therefore to induce transformation of a histidineless mutant of our Aerobacter aerogenes by cold-shocking it in the presence of wild-type DNA. The experiment was unsuccessful, so we do not 
report it in detail, but it does not exclude the relationship suggested because transformation in $A$. aerogenes has not been reported and the species may be non-transformable for quite unrelated reasons. Since DNase did not penetrate cold-shocked $A$. aerogenes it is possible, for instance, that the permeability barrier never becomes sufficiently 'open' in this species to admit molecules much larger than 14,000.

The fact that the lethal effect of RNase on Aerobacter aerogenes in distilled water was greater at $20^{\circ}$ than $0^{\circ}$ does not necessarily conflict with the conclusion that cold shock affects the permeability of susceptible organisms. Bacterial adsorption of enzyme was considerable from solution in distilled water but small from solution in saline phosphate buffer. Surface attachment of RNase is likely to facilitate its entry into the bacteria and the subsequent enzymic activity would be greater at $20^{\circ}$ than at $0^{\circ}$. The progressive inhibition of both adsorption and the lethal effect of RNase at $20^{\circ}$ by increasing concentrations of sodium or potassium chloride strongly suggests a relationship between the two phenomena.

The mechanism of the protective effects of magnesium ions, leakage products from chilled bacteria and sucrose against both cold shock and the lethal effect of RNase are not clear. These substances may affect bacterial permeability at $0^{\circ}$, thus preventing the entry of RNase, or they may inhibit the activity of the enzyme during subsequent incubation of the bacteria on growth medium. The latter suggestion is certainly possible in the case of magnesium which is known to stabilize isolated ribosomes (see review by McQuillen, 1962) and to diminish RNA degradation in heat stressed Aerobacter aerogenes (Strange \& Shon, 1964). The fact that cold shock stimulates autodegradation of RNA makes it evident that interference with permeability control is not the sole traumatic consequence of cold shock, though available evidence indicates that it is the primary one.

We are indebted to Mr A. G. Ness for some analyses, Major L. H. Kent and Mr J.H. R. Slade for the preparation of anilino-naphthalene-8-sulphonate and Mr J. M. Boyle for the histidineless mutant of Aerobacter aerogenes. Mr J. R. Hunter performed the experiments on freezing and thawing.

\section{REFERENCES}

Bracher, J. (1955). The action of ribonuclease on living cells. Publ. Staz. Zool. Napoli, $27,146$.

Crestrield, A. M., Stein, W. H. \& Moore, S. (1962). On the aggregation of bovine pancreatic ribonuclease. Archs. Biochem. Biophys. Suppl. 1, 217.

Gorrill, R. H. \& McNeIL, E. M. (1960). The effect of cold diluent on the viable count of Pseudomonas pyocyanea. J. gen. Microbiol. 22, 437.

Groth, D. P. (1956). Ribonuclease inhibition of protein synthesis in Bacillus megaterium. Biochim. biophys. Acta, 21, 18.

Hegarty, C. P. \& Weeks, O. B. (1940). Sensitivity of Escherichia coli to cold-shock during the logarithmic growth phase. J. Bact. 39, 475.

Josefsson, L. \& LAGERstedT, S. (1962). Characterization of ribonuclease and determination of its activity. Methods of Biochemical Analysis, 9, 64.

McQuillen, K. (1962). Ribosomes and the synthesis of proteins. Prog. Biophys. biophys Chem. 12, 69.

Matthews, M. M. \& Sistrom, W. R. (1960). The function of the carotenoid pigments of Sarcina lutea. Arch. Mikrobiol. 35, 139.

Meynel, G. G. (1958). The effect of sudden chilling on Escherichia coli. J. gen. Microbiol. 19, 380. 
Mitchison, J. M. (1963). Patterns of synthesis of RNA and other cell components during the cell cycle of Schizosaccharomyces pombe. J. cell. comp. Physiol, 62 (2), 1.

Morse, M. L. \& CARTER, C. E. (1949). The synthesis of nucleic acids in cultures of Escherichia coli, Strains $B$ and $B / R$. J. Bact. 58, 317 .

NewTon, B.A.(1954). Site of action of polymyxin on Pseudomonas aeruginosa : antagonism by cations. J. gen. Microbiol. 10, 491 .

Postgate, J. R., Crumpton, J. E. \& Hunter, J. R. (1961). The measurement of bacterial viabilities by slide culture. J. gen. Microbiol. 24, 15 .

Postgate, J. R. \& Hunter, J. R. (1961). On the survival of frozen bacteria. J. gen. Microbiol. 26, 367.

Postgate, J. R. \& Hunter, J. R. (1962). The survival of starved bacteria. J. gen. Microbiol. 29, 233.

Postgate, J. R. \& Hunter, J. R. (1963). Metabolic injury in frozen bacteria. J. appl. Bact. 26, 405.

Sherman, J. M. \& Albus, W. R. (1923). Physiological youth in bacteria. J. Bact. 8, 127.

Strange, R. E. \& Dark, F. A. (1962). Effect of chilling on Aerobacter aerogenes in aqueous suspension. J. gen. Microbiol. $29,719$.

Strange, R. E., Dark, F. A. \& Ness, A. G. (1961). The survival of stationary phase Aerobacter aerogenes stored in aqueous suspension. J. gen. Microbiol. 25, 61.

Strange, R. E. \& Ness, A. G. (1963). Effect of chilling on bacteria in aqueous suspension. Nature, Lond. 197, 819.

Strange, R. E. \& Shon, M. (1964). Effects of thermal stress on viability and ribonucleic acid of Aerobacter aerogenes in aqueous suspension. J. gen. Microbiol. 34, 99.

Young, F. E. \& Spizizen, J. (1961). Physiological and genetic factors affecting transformation of Bacillus subtilis. J. Bact. 81, 823. 